\title{
A DISCUSSION OF INTELLECTUAL HISTORY, JURISPRUDENTIAL THEORIES AND FEMINISM IN THE ERADICATION OF EPISTEMIC VIOLENCE IN SOUTH AFRICA
}

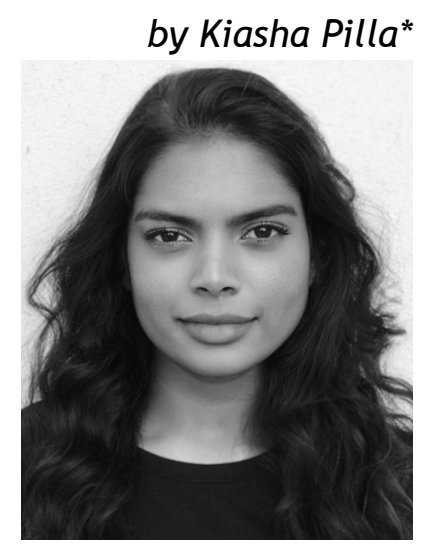

\section{Introduction}

This analysis and discussion of intellectual history, along with analysing theories concerned with legal pluralism, provides insight into the ideas and ideologies currently influencing jurisprudence that aims to eradicate epistemic violence. This paper will illustrate how the aforementioned analysis, along with the concept of transformative constitutionalism, actively contributes towards the development of jurisprudence that aims to diminish epistemic violence and the inequality that emanates from it. The paper will illustrate how theories concerned with legal pluralism, traditions and ideologies, such as Marxism, Black Consciousness, feminism and religion, all play a role in contributing towards the development of a critical jurisprudence that will aim to eradicate epistemic violence in several sectors of the South African society. This paper will further illustrate how feminism as an ideology, and in the field of sociological law, can uncover and subsequently empower hidden and marginalised narratives, thereby promote the eradication of epistemic violence. In addition, the paper will include an analysis of a feminist poem by a South African feminist scholar to highlight the relevance of the ideology of feminism in combatting epistemic violence.

* Third year LLB student, University of Pretoria. 


\section{How does intellectual history uncover and identify the roots of epistemic violence?}

Peter Vale discusses how South African intellectual history influences the change in ideas, and subsequently South African jurisprudence. ${ }^{1}$ Vale describes intellectual history as a change in ideas and ideologies, and uses this description to illustrate the 'migration of ideas to South Africa' and how this led to the development of South African intellectual history. ${ }^{2}$ Vale describes how the 'manifestation of ideas leads to the ideas influencing the ambitions of individuals and institutions', and how this pertains to South African society. ${ }^{3}$ The manner in which the 'intellectual traditions interacted with the South African struggles' is also used to highlight the importance and relevance of intellectual history in the development of South African jurisprudence. ${ }^{4}$ Vale then shows how the development of ideas and the migration of ideas to South Africa led to the 'rejection of indigenous knowledge and the embracing of English and Dutch traditions', and it must be acknowledged that this is essentially a form of epistemic violence. ${ }^{5}$ The concept of 'Little England on the Veld' and the exclusive embracing of Dutch and English knowledge marginalised indigenous peoples and their knowledge. ${ }^{6}$ This is perhaps one of the earliest forms of epistemic violence in South African jurisprudence. The development of ideologies and ideas through the study of intellectual history, according to Vale, is illustrative of the development of epistemic violence accordingly. ${ }^{7}$ The inception of epistemic violence in South Africa, according to Vale's findings, seems to be attributed to the influence of colonialism and, subsequently, the system of apartheid. ${ }^{8}$

Savo Heleta concurs with Vale's conclusion on this matter, as she acknowledges that "the persistence of epistemic violence in postapartheid South Africa is rooted in colonial and apartheid exploitation and racism". 9 Heleta argues that "colonial and apartheid marginalisation, racism and exploitation live on in many spheres of life and work'. ${ }^{10}$ This statement is accurate when considering the current prevalence of epistemic violence in South Africa, and in

$1 \quad \mathrm{P}$ Vale Of ships, bedraggled crews and the miscegenation of ideas. Interpreting intellectual traditions in South Africa (2014) 3.

2 Vale (n 1) 3.

3 As above.

As above.

Vale (n 1) 8.

Vale (n 1) 9.

Vale (n 1) 8.

As above.

S Heleta, 'Decolonisation of higher education: Dismantling epistemic violence and Eurocentrism in South Africa' Transformation in Higher Education Journal 1(1) 20163.

10 Heleta (n 9) 9. 
several aspects of South African society, such as race, gender and religion. Heleta further analyses epistemic violence and its roots by acknowledging that the emancipation of black South Africans cannot be fully achieved unless the 'many structural imbalances, remaining inequalities and stumbling blocks' that exist in the sphere of epistemic violence, are removed. ${ }^{11}$

Through these studies of intellectual history and the development of ideologies surrounding the acceptance of colonial knowledge and the roots of epistemic violence, it becomes evident that epistemic violence is indeed entrenched in South African society, and is apparent in many facets of society, including the legal sphere. Judge Weinkove's statement is one of the many examples of this entrenchment of epistemic violence, pertaining to class in particular. ${ }^{12}$ Epistemic violence has undoubtedly affected particular classes and groups of people within South Africa, some more than others, with the reality of historically marginalised classes and groups being directly affected by the phenomenon. Epistemic violence is responded to by intellectual history, through the identification of the roots of epistemic violence and its effects on society. Intellectual history, as illustrated by Vale and Heleta, is capable of exposing the nature of epistemic violence and providing us with the necessary background on the matter. This aids in identifying the specific sectors of society that epistemic violence most impacts. Once this is achieved, a more critical jurisprudence, which encompasses solutions for the problem of epistemic violence, can be developed through the law, using traditional and modern theories such as feminism, Black Consciousness and legal pluralism.

\section{How does a restricted jurisprudence contribute towards the prevalence of epistemic violence?}

Douzinas and Gearey explore the exposition of the shift from a general to a restricted jurisprudence. ${ }^{13}$ This is illustrative of a 'story of decline' seen in both South African jurisprudence and in the reemergence of epistemic violence in a democratic society where marginalisation is still very prominent. ${ }^{14}$ The shift from a general to a restricted jurisprudence encompasses the 'gradual diminution of the scope of the law' and the prominence of epistemic violence can

11 Heleta (n 9) 1.

12 SF De Beer Urban social movements in South Africa today: Its meaning for theological education and the church (2014) 2.

13 C Douzinas and A Gearey From restricted to general jurisprudence (2005) 3.

14 Douzinas and Gearey (n 13) 4. 
be partly attributed to this. ${ }^{15}$ Epistemic diversity and epistemic justice can be achieved if we are able to include previously marginalised narratives and voices that are excluded by our current jurisprudence. One of the most crucial steps in ensuring the aforementioned can occur, is the development of a more general jurisprudence. This would entail a culmination of the various legal traditions and ideologies that exist within the scope of law, and ideologies developed in different disciplines such as psychology, philosophy, etc. A more general jurisprudence also allows for the inclusion of narratives that were previously excluded: narratives stemming from these disciplines. Douzinas and Gearey state that 'a general jurisprudence examines ways in which subjectivity is created as a site of freedom and of subjection', and this illustrates how a general jurisprudence encourages emancipatory methods for the marginalised narratives in society. ${ }^{16}$

\section{Analysing epistemic violence through the lenses of various intellectual traditions}

The theories concerning legal pluralism, like intellectual history and a general jurisprudence, contribute towards the development of a critical jurisprudence that will alleviate forms of epistemic violence. Veitch's analysis of legal pluralism is centred around the concept of 'presenting an alternative paradigm to the law'. ${ }^{17}$ When compared to legal modernity, this explains how the scope of law is problematic in South African jurisprudence. The law is perceived as 'lawyer's law', and this highlights how 'state-law is hindered by non-state law'.18 Veitch describes how it is necessary to focus on the development of contemporary legal pluralism, as it encourages the growth of empirical socio-legal studies, inclusive of ideologies such as feminism, Black Consciousness and religious traditions. ${ }^{19}$ Contemporary legal pluralism assists in the development of these ideologies. It also encourages greater focus on how law operates with these ideologies in practice, instead of encouraging a focus on the doctrinal analysis of law, which pertains to only focusing on 'law in the books'. ${ }^{20}$ This focus on contemporary legal pluralism encourages the development of a critical jurisprudence that considers the effects of law and how law is practiced in society. This further encourages a jurisprudence that is more general and inclusive on contemporary ideologies.

15 As above.

16 Douzinas and Gearey (n 13) 10.

17 S Veitch Legal pluralism (2014) 207.

18 As above.

19 Veitch (n 17) 208.

20 As above. 
Veitch discusses how law is at the centre of Marxist theory and how the Marxist concept of economy shapes society in contemporaneity. ${ }^{21}$ This illustrates how certain Marxist economic theories and theories on capitalism can be used to make a distinction between a more inclusive jurisprudence and a restrictive jurisprudence that is influenced by these theories. The Marxist concept of economy is perceived as the determinant of 'the shape and function of all institutions in society'. ${ }^{22}$ This concept can be used to interpret the way in which a state's economy functions in relation to its societal facets however, it is not inclusive of many other ideologies and theories that influence our current jurisprudence. Another Marxist theory can be used to make a distinction between theories hindering the development of an inclusive jurisprudence and those developing it: Identity in law as legal subjects. ${ }^{23}$ Marx stated that one's sense of identity is dependent on one's interaction with others and that 'as legal subjects we are tied together by money and our ability to buy and sell'. 24 This view on the concept would encourage a more restrictive jurisprudence however, the law 'abstracts from social identity', which encourages a more inclusive jurisprudence. ${ }^{25}$ Veitch further analyses Foucault's concept of juridical regression in his findings on power and discipline and how this hinders the development of an inclusive jurisprudence. ${ }^{26}$ This concept pertains to the regression of traditional law and ideologies, perhaps due to lack of modern relevance, and the emergence of theories relating to modernity. When taking cognisance of this, it is important to consider traditional ideologies and theories of law and in other disciplines, especially for the development of a more inclusive jurisprudence.

Mabogo P More discusses the philosophical roots of one of these traditions namely, Black Consciousness, in 'The Intellectual foundations of the Black Consciousness Movement'. 27 He discusses how the political and intellectual ideas surrounding Black Consciousness must be understood by looking at the 'philosophical, political, social and religious milieu from which they emanated'.28 This is a prime example of an ideology that is extremely inclusive and would contribute towards developing a more general critical jurisprudence. The crux of More's discussion is the definition of Black Consciousness as 'both a movement and a philosophy, and how 'Black Consciousness has always been the only liberation movement whose

21 S Veitch Law, ideology and legitimation: The Marxist critique (2018) 227.

22 As above.

23 Veitch (n 21) 228.

24 Veitch (n 21) 227.

25 As above.

26 M Foucault Displacing the juridical: Foucault on power and discipline (1984) 236.

27 PM More The intellectual foundations of the Black Consciousness Movement (2014) 173.

28 As above. 
ideas were generally referred to as a philosophy'. ${ }^{29}$ The inclusion of a philosophical approach to an ideology that emancipates and demarginalises black South Africans signifies an important method in developing a more inclusive and general jurisprudence. Black Consciousness is essential for the de-marginalisation of previously oppressed black South Africans. This is essential for the development of a jurisprudence that is capable of the eradication of epistemic violence. More states the Black Consciousness is importantly inclusive and states that 'Black Consciousness is a form of consciousness, a mode of being-in-the-world'.30 More further discusses how Black Consciousness 'led to the emergence of black theology within the Black Consciousness Movement', and how this led to both concepts being advocated for by the likes of Desmond Tutu and Allan Boesak. ${ }^{31}$ This is indicative of the fact that the ideology of Black Consciousness was inclusive of religion too, and capable of contributing towards a jurisprudence that can eradicate epistemic violence pertaining to both race and religion.

The same inclusivity can be attributed to Islamic intellectual traditions in South Africa as explored by Muhammed Haron in 'Islam, Intellectuals and the South African question'. ${ }^{32}$ Harom explores the contributions of Muslim activists and thinkers towards securing an 'intellectual tradition' in the country, and thereby contributing towards a developing, more general jurisprudence, capable of eradicating religious epistemic violence. Haron highlights the emergence of the 'humanist approach' to Islamic intellectual traditions, which entails a more contemporary interpretation of Islam. ${ }^{33}$ This contemporary interpretation is inclusive of the relation of Islamic traditions and culture, and the ability to adapt to 'the demands of modernity and political change'. ${ }^{34}$ According to this approach, the vibrancy and critical nature of Muslims must be highlighted in order to give a sense of human agency to this group of people, which is illustrative of the ability of Islamic intellectual traditions to contribute towards eradicating epistemic violence. ${ }^{35}$ Islamic religious organisations and the leaders of these organisations, are typically intellectuals that had entered the struggle against apartheid and joined political organisations such as the Natal Indian Congress and the SACP in the 1950's and 1960's. These intellectuals also contributed towards 'international Muslim resurgence' which illustrates the contributions of Islamic intellectual traditions towards

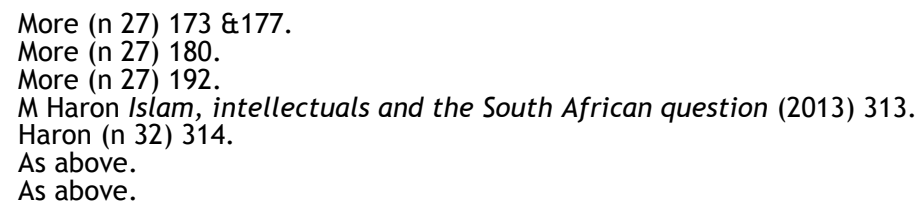


eradicating racial inequalities, and thereby, eradicating epistemic violence to an extent. ${ }^{36}$

\section{Understanding the prominence of gender- based epistemic violence through feminism}

An increasingly prominent form of epistemic violence is genderrelated epistemic violence, which is addressed by the ideology of feminism. Van Marle in 'We exist, but who are we? Feminism and the Power of sociological law', questions whether law has been decentred by feminism or not, with reference to Carol Smart's claim that feminism can indeed decentre law. ${ }^{37}$ Van Marle addresses Smart's argument against the development of a feminist jurisprudence by stating that it allows females to work at a conceptual level, enabling society to engage with both the power of the law and feminism. ${ }^{38}$ Van Marle also addresses Smart's claim that law has been decentred by feminism by arguing that the law is growing increasingly relevant in women's lives. ${ }^{39}$ I believe this to be a good argument against Smart's claims, as Van Marle's arguments encourage a strain of feminism that can combat the marginalisation of women through the application and practice of the law.

Helen Moffett specifies how feminism contributed towards both South African traditional and political traditions, and echoes Van Marle's arguments for the same contributions of feminism. ${ }^{40}$ Moffett also addresses the current marginalisation of women and feminism as an ideology, by examining how 'the actual political paradigms of feminism remain largely misunderstood or ignored'. ${ }^{41}$ Moffett makes two observations regarding the inclusion of women in society through the law and that contributes towards the ability of feminism to eradicate epistemic violence pertaining to gender. These observations are namely, that 'historically, women were active in the anti-apartheid struggle' and that 'women are numerically wellrepresented in government'. 42 She also highlights that this renders visible what had been erased and marginalised for centuries: 'women's history, work and cultural contributions'. 43 This is indicative of how feminism in law has the ability to give agency to the previously marginalised and contribute towards eradicating epistemic violence. Moffett analyses the feminist mechanisms used against

36 As above.

37 K Van Marle We exist, but who are we? Feminism and the power of sociological law (2012) 149.

38 As above.

39 As above.

40 H Moffett, Feminism and the South African polity: A failed marriage (2014) 219.

41 Moffett (n 40) 220.

42 As above.

43 Moffett (n 40) 221. 
apartheid, and how organisations such as the ANC Women's League and Black Sash were a product of different feminist groupings, according to race and class, becoming allies in the search for social change for women. ${ }^{44}$ This analysis is indicative of how feminism as an ideology was capable of grouping together women that were previously separated from one another in a social context. This was achieved by allowing them to find a common goal: that of being equal. This illustrates how feminism is able to eradicate this particular form of epistemic violence.

Jennifer Thorpe's poem, 'Order in the mother city', in Appendix A, illustrates how women of different backgrounds and of different social circumstances, living in the apartheid era, were divided by circumstance, but could relate on the basis of wanting to be emancipated from the shackles of patriarchy and domestic abuse. ${ }^{45}$ This particular example of feminist poetry gives us insight into how women that are domestically abused, irrespective of race or class, are marginalised in society, and how feminism can be used an emancipatory tool for women with very different narratives. If used in this way, feminism has perhaps the greatest potential for contributing towards the development of a jurisprudence that is more inclusive of upholding women's rights and protecting women, thereby assisting in the eradication of epistemic violence.

\section{Conclusion}

There are several theories and ideologies that can contribute towards the development of South African jurisprudence so that it encompasses the inclusion of more groups, races and types of people in society. Intellectual history is essential in analysing the root-causes of epistemic violence and in understanding the socio-economic and gender-based developments that resulted in marginalisation to this extent. The understanding of the narrowing of the scope of jurisprudential theory and the subsequent shift from a general to a restricted jurisprudence can greatly benefit South Africans in the legal field in cultivating possible solutions to epistemic violence. Analysing the effect of how law is practiced in society through the lens of legal pluralism can encourage the development of a jurisprudence that is more inclusive of contemporary ideologies such as feminism, Black Consciousness and religious traditions. The law has the ability to develop a jurisprudence like this through the influence of both traditional and modern legal philosophies, traditions and theories. In order for epistemic justice to be achieved, the law must envelop these philosophies, traditions and theories, especially those 
of feminism and Black Consciousness, which relate to perhaps the two most prominent forms of epistemic violence: gender and race.

\section{ANNEXURE A}

\section{Order in the Mother City - Jennifer Thorpe}

1 It was

2 The force of the wall

3 That propelled her face forward

$4 \quad$ And back into the foot

5 That kicked it.

6 The kicker danced

7 The dance of a victorious soldier.

8 For he was a warrior in a long standing campaign

9 Of dominance

10 And hate.

11 Behind the wall,

12 And hidden from view,

13 A young girl played on her swing set

14 Took selfies with her Ipad

15 Unaware of the violence beyond.

16 Her mother

17 Was not abused

18 Just disabused of the notion

19 That one day she would come home

20 To find dinner on the table.

21 Along the street

22 A more hopeful woman walked

23 Witnessed the scene

24 And called the police

25 To restore order.

26 The police arrived 
